\title{
CHALLENGES OF FAILED MARRIAGES AND THE IMPLICATIONS FOR DELINQUENCY
}

\author{
HabeEb AbDulrauf Salihu, Hossein GHolami ${ }^{l}$
}

\begin{abstract}
The study investigates the challenges of failed marriages and their implications for delinquency. The design of the study was a survey; purposive and snowballing sampling techniques were used to select 130 respondents. Triangulation of in-depth interviews and questionnaires were used as a framework for collecting information. Findings showed that there is a relationship between partners' experiences in failed marriages and delinquent behavior such as truancy, bullying, and children being out of parental control. It was established that infidelity and avoiding responsibility are the major factors responsible for failed marriages. Based on the findings, the study reinforces the claim that communication is an important element of a successful marriage. A marriage that involves too much blame, conflict, and verbal attacks keeps children away from home. Couples who experience difficulties should seek the assistance of marriage experts who may help them to identify problems and suggest ways to solve these.
\end{abstract}

KEYWORDS: challenges of failed marriage; abusive household; delinquency; implications; Ilorin; Nigeria

\section{INTRODUCTION}

Marriage has the potential to enrich spouses' lives and add to gratification of life. Nevertheless, marriages can also cause distress, put a strain on partners, and sometimes even cause harm (Hassouneh-Phillips 2001). However, it has become difficult in our present society for marriages with no solid foundation

\footnotetext{
1 Habeeb Abdulrauf Salihu is a PhD student at the Department of Criminal Law and Criminology, Allameh Tabataba'i University Tehran, Iran, e-mail: shol_dion@yahoo.com. Hossein Gholami is an Associate Professor at Department of Criminal Law and Criminology, Allameh Tabataba'i University Tehran, Iran, e-mail: gholami1970@yahoo.com.
} 
to survive the increasing explosion in immorality directly linked to the selfishness that has overwhelmed our society. Never before in human history has there existed an era so geared towards the idea of "me first" in marriage (Seltzer 2000). In fact, the notion that is common to young couples of today is that marriage is all about love, and love to them is all about individual satisfaction in terms of intimacy and material needs (personal fulfillment) (McCarthy - McCarthy 2005).

Changes in the worldwide social outlook have added to the downfall of marital relationships; waning religious institutions and values have also contributed to the demise of wedlock. This can be seen in the growing independence of genders (Booth et al. 1995; Tikumah 2009). With the advent of dual career families (a situation where both partners pursue an independent career or job), quarrels over the division of household tasks between partners have become a major cause of marital problems. This is because most couples nowadays agree about how these tasks and burdens should be shared, particularly childcare and household expenses, in contrast to the traditionally assumed responsibilities whereby wives take care of the household and children while husbands provide the income needed to support the family (Busari 2011; Bianchi - Milkie 2010). Consequently, the change in gender independence between men and women has resulted in a significant increase in the instability of marriage (McCarthy - McCarthy 2005).

Modernization, which has given rise to the development of urbanization, information technology, and modern society, has also belittled the concept of traditional marriage. It has rendered marriage immaterial, and made it no longer commensurate with today's expectations (Bumpass 1994). It has also allowed the forces operating outside the home to have a significant influence on the minds of family members who are now largely influenced by their work and relationships with colleagues and non-family friends through social media. As a result, the principal identities usually identifiable with the collective family no longer exist (Manning et al. 2007; Kaplan - Michael 2010). Today, attitudes permissive of fornication, adultery, rape and every form of promiscuity flood our societies through literature, movies and the arts (Buijzen - Patti 2003). Modern tales and legends disparage wedlock, and unfaithful celebrities routinely make the headlines instead of good examples of loyalty and fidelity (Ray - Kana 2010).

Consequently, marriage has become a "throw-away-commodity," even perceived by some as mere household garbage to be used and thrown out (Busari 2011). It seems that the customary vow "till death do us part" is no longer applicable, but lasts only as long as "my needs" are provided for, and the failure of a spouse to meet the needs (usually financial and sexual) of the other spouse creates a marital crisis. Typically, problems occur in the 
home when stress and unresolved conflicts generate worry and hatred, which later becomes too severe to be handled. This often results in resentment, frustration, and hopelessness, which in turn have grave impacts on the wellbeing of children (Fincham - Steven 1999). The negative feelings between couples sometimes make them do despicable things such as exchanging harsh words and beating and physically abusing each other in the presence of children. Couples sometimes disengage completely from one another without any consideration for their children (Busari 2011). It is against this backdrop that this study examines the challenges faced by couples experiencing failed marriages and the implications for juvenile delinquency. The purpose of this study, therefore, is to examine the implications of failed marriages on delinquent behavior among children living in (such homes) Ilorin metropolis, Nigeria. Specifically, the study was designed to:

a. Describe the major factors that may be responsible for failed marriages,

b. Explore the pattern of children-parent relationships in failed marriages,

c. Investigate the relationship between failed marriages and delinquent behavior, and

d. Suggest adaptable steps for managing and coping with failed marriages and the affected children.

\section{CONCEPTUALIZING SUCCESSFUL AND FAILED MARRIAGE}

Just like individuals, all marriages are not alike. However, research in this area has found similarities among husbands and wives in healthy marriages. Wood et al. (2012) like Ooms (2007) and Burr (1976) asserted that couples in successful marriages are committed and giving people, and this generosity implies that they satisfy their spouse's emotional needs, do not keep scores, spend much time seeking advice and exchanging ideas, and express gratitude and admiration. In addition, commitment to marriage values, sharing common interests and working to achieve them, openness of opinions and feelings (communication), trust, role model virtues, and sexual desire and fulfillment against all odds are the basic features of a successful marriage (Wood et al. 2014).

However, Glenn and Michael (1984), Perry and Steven (1992) and Kozu (1999) observed that a failed marriage results from a gradual accumulation of aggravation, hurt, resentment, ego, and miscommunication in a relationship. Perry and Steven (1992) further stated that each time one or both spouses choose to ignore signs of discord and avoid communicating, what each of them is really feeling is that their relationship is coming closer to the end. Grych et al. (1992) 
asserted that partners in a failed marriage experience feelings of insecurity and need (i.e. deprivation) when not around their partners as they tend to critically judge each other's differences when conflict arises such that they are unable to solve problems; they feel stifled if the other partner is not ready to hear them out or take their point of view into consideration, thereby resulting in withdrawal of intimacy, sex and love. Glaser (2002) also noted that, in an unhealthy marriage, partners do not communicate openly and honesty disappears. Lies and withholding important information from each other become the order of the day. Similarly, partners complain to third parties about their spouses instead of talking to them and settling problems, thereby diminishing the quality of the marital relationship.

Wood et al. (2012) noted that frequent disagreements, abusive behavior, and disrespect among couples are signs that all is not well in a marriage. Wood et al. further stated that some couples resort to constant name-calling or rude behavior and bringing up issues that purposely hurt the other person. Some partners not only curse each other but may even throw objects at each other. Gottman (1993) added that fighting and persistent physical abuse such as beating, biting, grabbing, punching, slapping, kicking or shoving, forced sex, and the use of weapons in extreme cases are common among partners experiencing failed marriage. In the same line, Fincham and Steven (1999) also observed that the act of approaching a conversation with quarrel, accusations, and deprecating comments are indications of a failed marriage.

\section{Factors that may result in failed marriage}

it is a common belief that stress and fighting over money constitute one of the major problems that couples face. In tough economic times, for instance, financial strain can actually cause misunderstanding and fights and more conflict over things unrelated to money, as well as money-related issues (Gottman 1993). Other factors may include:

Poor communication: Communication has been identified as one of the most fundamental elements of a healthy marriage. Communication allows partners to share and discuss their challenges and the problems they encounter within and outside the home, thus it makes partners feel loved. An absence of communication, on the other hand, complicates issues, undermines the foundation and purpose of marriage, makes partners lose interest in the union and can have severe consequences for the ability of the couples to sustain the union (Raush et al. 1974; Gottman 1993). 
Sexual Fulfillment: Sexual dissatisfaction is a sensitive subject in most marriages which most partners find very difficult to discuss openly. In a situation where a partner summons the courage to raise the issue, expecting cooperation from the other in terms of solving the problem, it is often dismissed or minimized by the other partner and sometimes turns into fighting (Cleary - David 1983). As Tikumah (2009) has noted, complaints about sexual dissatisfaction in marriage are hard to express and unpleasant to receive. Tikumah further argued that sexual dissatisfaction among couples in most cases leads to emotional disengagement, which consequently leads to infidelity.

Economic and Educational Disparity: Beckham (1992) noted that women who have married down the socioeconomic ladder experience smaller gains from marriage in terms of the fulfillment of their material needs, and thus may over time feel deprived and enjoy the marriage less, potentially resulting in a failed marriage. In addition, a wide educational gap between spouses may be a major contributor to a failed marriage. As Omage (2013) argued, when there is a wide gap in spouses' levels of education, there is the likelihood of discrepancies in their attitudes and approaches to life and disagreement about how to handle issues. These differences may make it very difficult for partners to get along and maintain a peaceful and stable home.

Age: Age is an important factor that sometimes contributes to problems in marriage. Booth and John (1985) asserted that age is a significant factor that may result in marital instability. For instance, the husband-wife age gap is a factor that can cause a problem in the home if care is not taken. If the wife is older than the husband, the likelihood of instability is increased significantly, most especially in Africa where major importance is attached to age. Similarly, couples who are very young when married are believed to be at risk of experiencing unstable marriages because the necessary experience needed to establish a happy home is potentially yet to be gathered (Blood - Donal 1960).

Parental approval: Parental approval is another factor related to marriage success for two reasons: first, approving parents are more supportive (emotionally, morally and financially) and second, disapproving parents are not always supportive and usually shun couples when they face turbulence in their union (Ekiran 2003). This seems to be a common problem couples face, most especially among the Yoruba ethnic group in Nigeria. When in-laws give their approval to a marriage, they render the necessary assistance to the couple even if they both face other challenges in their union. Parents may be able to mediate and help solve problems. However, if a parent objects to a union, the probability of the couple maintaining a stable home life is zero (Burns 1984). A survey conducted by Richard and Amy (2001) in California, revealed that $87 \%$ of marriages not supported by either of the parents (in-laws) ended in battles and separation. 
Issues regarding children: Issues regarding children have also been identified as another factor affecting marriages. Experts believe that crises erupt in marriages when there is less glue to hold the marriage together, one source of which is children (Waite - Lee 1991). In some marriages, children are the cause of conflict, but generally children are a stabilizing factor in marriages, and when children are absent, a marriage is likely to be rocked by minor storm (Hetherington et al. 1998). In most cases, peace and order usually reign in marriages prior to the arrival of the first child. There may be conflicts, but they are not usually frequent and are often easy to resolve (Waite-Lee 1991). After the first child arrives, couples are faced with conflicts they have never encountered before. Their lives begin to change as they assume new responsibilities. These changes require the couple to make new decisions, which may lead to conflicts of interest (Booth - John 1985).

Prior Marriage: Matthews et al. (1995) argued that an earlier marriage of a husband or wife may increase the likelihood of conflict and dissolution of a later marriage. A husband may have children from a previous wife and, as Robles et al. (2014) noted, the presence of such children may decrease the gains from the current marriage, thereby leading to crisis. In addition, for women prenuptial conception or a child carried into a new marriage is more likely to be associated with high risk of failed marriage. Similarly, the issue of the legitimacy of a child is a serious factor that can turn a happy home into a combat arena.

Reason for getting married: Partners marry for different reasons: some get married with so many expectations and aspirations. When such expectations go unfulfilled after some years of marriage, a sense of disappointment sets in, and they may begin to see nothing good in the marriage. Carrère et al. (2000) claimed that the reason couples get married is an important factor that can contribute immensely to the success (failure) of a marriage. Usually, marriages that began and build on genuine understanding and caring succeed better than those that start for the wrong reasons, such as a desire to escape home, to rebel, or to obtain social and financial status (Edin - Joanna 2005).

From the foregoing, it can be observed that there is no specific factor responsible for failed marriages. The source of problems may be a combination of the factors highlighted above, or something entirely different.

\section{Challenges faced by couples in failed marriages}

Couples in failed marriages do not seem to obtain the benefits that a marriage can offer. In fact, the stress may make them less healthy. Choi and Nadine 
(2008), and Kiecolt-Glaser and Tamara (2001) have proved that when one or both partners become overwhelmed and flooded with anger and resentment, this results in psychological changes in the body such as an increased heart rate and abnormal blood pressure; these psychological responses negate the ability to effectively resolve the conflict.

Other challenges may include a lack of intimacy (affection and sexual relations) - affection and sexual relations are the glue which hold a marriage together. Sexual intimacy, for instance, is typically the one major form of contact which separates the relationship of a couple from one with ordinary friends or roommates. However, it is difficult for couples experiencing a failed marriage to engage in sexual intimacy. One partner may ignore the other sexually, while the denial of a partner's sexual intimacy needs may amount to emotional abuse, making the other feel unwanted, undesired, unworthy, and unattractive (Beckham 1992). In addition, taking a partner for granted, physical abuse, and the use of frequent threats (threats are often made in a situation of desperation, or when one partner senses that a situation is out of control) as well as silent treatment - a situation where a partner behaves in an unreceptive manner in response to a particular issue or shows their grievance by ignoring or not speaking to the other partner - are also notable reasons for marriage failure (Kozu 1999).

\section{IMPLICATIONS FOR DELINQUENCY}

O'Hagan (1993) and Davies et al. (2008) noted that when tension and conflict are the norms in any unhappy marriage, parent-child interactions and relationships usually show some sign of strain. Conflicts drain the necessary and valuable resources that hold the relationship together and make way for inconsistent and ineffective parenting. Marital conflicts have a devastating impact on children because they can trigger psychological and behavioral problems in children such as depression, anxiety, aggression, and withdrawal. Correspondingly, while attempting to obtain a clearer view of how children respond to parental conflicts, Davies and Cummings (1994) used Emotional Security Theory (EST) to explain that children's elevated response to parental conflicts develops from repeated exposure to such destructive behavior which increases the likelihood they will have psychological problems.

Furthermore, emotional deprivation or neglect is a form of abuse suffered by children living with parents who are experiencing a failed marriage. Emotional deprivation is an important and sensitive form of neglect that a child or an adult may encounter having been denied emotional attention by the people 
who are supposed to provide it. Emotional loneliness in adult life may be a result of neglect and unsupportive relationships in childhood (Kirman 1973). Using Social Control and Attachment theory, Hoeve et al. (2012) stressed that emotional deficiencies in children often occur when there is lack of attachment (or poor attachment) to parents. Hoeve and colleagues further noted that the effects of this go far beyond physical abuse, which is usually expressed in beatings, bruises and broken bones. Accordingly, adolescents with poor attachment relationships have higher levels of delinquency. Glaser (2002) also observed that a child who suffers emotional deprivation may be just as damaged as if they were frequently beaten or subjected to other forms of physical abuse. Glaser further noted that emotional deprivation is more likely to occur among children who live in families where mothers themselves are in need of emotional support. These mothers might have been devastated by the conditions around them and thereby lost the caring ability normally associated with guardianship.

Kirman (1973) also observed that the early years of any child's life are crucial to their development. This is because during these early years children go through different phases of development, including interacting with the personalities of people around them. O'Flynn (1994) using Object Relations Theory observed that if necessary components such as love, caring, emotional support and a favorable environment are lacking, a child may be at a high risk of psychological disorder, antisocial attitudes, aggression, and challenges regarding managing anger as an adolescent. This suggests that the neglect and unsatisfactory relationships experienced during early childhood can have long-term effects on children.

Lerner and Domini (2013) established that partners not only fight (misunderstand, neglect, etc.) each other, but they in effect neglect and pass on wrong ideas to their children. Failed or unhealthy marriages deteriorate relationships between the child and at least one parent. It has also been observed that the children of failed marriages may acquire the same incapacity to work through conflict as their parents. Lerner and Domini have further stated that daughters from such families find it more difficult to value their femininity, and sons frequently demonstrate less confidence in their ability to associate with women, either romantically or at work.

\section{METHODOLOGY AND SAMPLE}

The research described herein used both a qualitative and quantitative descriptive approach to identifying and analyzing issues relating to the research objectives. A variety of sampling methods were employed, including purposive and snowballing 
techniques. In-depth interviews and questionnaires were used as a framework for collecting information about the challenges faced by couples in failed marriages and the implications for delinquency. The researchers interviewed one married man and two married women of different age who were experiencing turbulence in their marriages and two children (aged 13 and 15) who were experiencing a failed marriage. In addition, questionnaires were administered to a total of 125 respondents (63 counselors, and 62 social workers). These experts were believed to have the background and adequate knowledge of people and families experiencing failed marriage. The information gathered was then analyzed using content analysis and Statistical Package for Social Scientists (SPSS) to generate simple percentage, frequency distribution, and chi-square statistics for some factor analyses of the responses relating to the research questions.

The demographic distribution of the respondents revealed that $57 \%$ of the respondents were male and $43 \%$ female. The majority of respondents $(48.8 \%)$ were between the ages of 36-40 years old, $30.4 \%$ between $30-35$ years old, and $20.8 \%$ above 41 years of age. In addition, $60 \%$ of the respondents were married; $4 \%$ single; $15.2 \%$ were divorced and $20.8 \%$ were widows/widowers. In terms of work experience, $27.2 \%$ of respondents had been in their profession for $1-10$ years, $38.4 \%$ had $11-20$ years' experience, and $34.4 \%$ had 21 years' work experience or more (Appendix).

\section{RESULTS AND DISCUSSION OF FINDINGS}

Regarding our first research question, Table (1) presents respondents' responses to a question about the factors responsible for failed marriages.

Table 1 Major factors responsible for failed marriage

\begin{tabular}{|c|c|c|c|c|}
\hline Items & Counselors & Social workers & Frequency & Percentage \% \\
\hline Financial issues & 9 & 10 & 19 & 15.2 \\
\hline Unfulfilled expectations & 3 & 4 & 7 & 5.6 \\
\hline Division of domestic responsibilities & 0 & 2 & 2 & 1.6 \\
\hline Problems regarding children & 3 & 0 & 3 & 2.4 \\
\hline Infidelity & 28 & 30 & 58 & 46.4 \\
\hline Parental approval prior to marriage & 1 & 3 & 4 & 3.2 \\
\hline Avoiding responsibilities & 19 & 13 & 32 & 25.6 \\
\hline Total & 63 & 62 & 125 & 100 \\
\hline
\end{tabular}

Source: Based on authors'survey (2016). 
Table 1 shows that $46.4 \%$ of respondents (counselors $n=28$, and social workers $\mathrm{n}=30$ ) believed that infidelity is the major factor behind failed marriages among couples, $25.6 \%$ claimed that avoiding responsibilities in the family is the cause, $15.2 \%$ were of the view that financial issues in the family were the major contributor to the incidence of failed marriages, $5.6 \%$ blamed unfulfilled expectations in the family, $3.2 \%$ specified parental approval prior to the marriage, $2.4 \%$ believed that the issue was related to problems with children, while $1.6 \%$ of respondents highlighted the division of domestic responsibilities. Thus the majority of respondents held that infidelity is the major factor in failed marriages among couples in the Ilorin metropolis.

Moreover, concerning the factors responsible for failed marriage, partners who were actually experiencing a failed marriage responded in the following manner: Female Respondent 1 observed that "When the love partners share disappears, every other problem occurs. In most cases, financial difficulty causes a problem in the house. When the wife complains, it may result in verbal abuse and even beating. Avoiding responsibilities in the house as a husband or father is also one of the ways men use to get back at their wives when they have done something wrong. Most of them provide for their children needs, but the wife's needs such as intimacy and time are denied. Above all, infidelity is the major cause of marital discord. When your husband is having an affair and you cannot do anything about it, you will be afraid to talk about it because you never know what the response might be."

Similarly, Female Respondent 2 stressed that "Financial issues are a general problem in every marriage, I think. They become much more of a problem when the husband tries to boycott his responsibilities as husband and father with flimsy excuses, or an I-don't-care attitude in the name of 'I don't have money'. It pains when you realize your husband is refusing to provide for the family simply because he dislikes his wife. I think the major factor behind unhealthy marriages or homes in our society is infidelity. When a man starts having extramarital affairs, he will typically begin to avoid responsibilities, most especially when the wife complains about the affair."

Furthermore, the Male Respondent noted that "Adultery or unfaithfulness is what no man can accept. This poses a serious challenges to marriages. In my case, for instance, I am a state civil servant and everyone is aware of my poor salary. Despite this, I tried to provide for my family within my capability. It is however disheartening that the woman I struggle to provide for cheats on me. I decided not to send her away because of my children, but I think things will never be the same again between us.... We did have arguments over money before the incidents. I think issues surrounding money are a general problem in every home. But the major cause of a failed marriage is infidelity." 
From the perceptions of the counselors and social workers and in the opinions of people actually experiencing failed marriage, it is highlighted that infidelity and avoiding responsibilities are the major factors responsible for failed marriages, although other factors such as financial issues are also in play.

Table 2 Children-Parent relationships in failed marriages

\begin{tabular}{|c|c|c|c|c|}
\hline Items & Counselors & $\begin{array}{c}\text { Social } \\
\text { workers }\end{array}$ & Frequency & Percentage\% \\
\hline Cordial with both parents & 0 & 0 & 0 & 0 \\
\hline Resentment towards one of the parents & 21 & 25 & 46 & 36.8 \\
\hline Feeling unsafe in relation to both parents & 23 & 15 & 38 & 30.4 \\
\hline Feeling reserved & 19 & 22 & 41 & 32.8 \\
\hline Total & 63 & 62 & 125 & 100 \\
\hline
\end{tabular}

Source: Based on authors'survey (2016).

Table 2 presents respondents' responses to a question about patterns of children-parent relationships in failed marriages. The table shows that $36.8 \%$ of respondents were of the view that children in a failed marriage resent one of the parents, $32.8 \%$ believed that children living with parents experiencing failed marriage feel reserved and withdrawn, $30.4 \%$ perceived that children in failed marriages feel unsafe relating to both of the parents, but $0 \%$ (none of them) believed that children enjoyed a cordial relationship with both parents in a failed marriage.

Additionally, concerning the interviews that were conducted with the two children living in failed marriage, the children responded to the question about their relationship with their parents in the following manner; Child 1 noted that "I saw my daddy and mummy shouting at each other. Sometimes mummy cries when daddy beats her. She left the house many times and came back after some days when grandma came around to talk to daddy. I and my sisters used to cry. We love to stay with mummy because we love her and don't want to see her cry again.....we love daddy too but we are always afraid of him."

Also, the second child (Children 2) said that "I don't feel safe with my father because he makes my mother cry all the time. They often make a noise and fight in the house. My father often told me to warn my mother to stop challenging him....I talk to my mother when I have a problem or need something. She often told me to talk to my father about it, but I am not always happy staying with him because he yells."

Furthermore, from the interview with the women experiencing a failed marriage, Female respondent 1 noted that "My children seem to be more comfortable around me as the mother. They prefer to share their problems 
with me or ask for anything they need. They find it difficult (most especially my daughter) to face their father. I guess they are always afraid." Similarly, Female respondent 2 also noted that "My son once told me that we should pack and leave the house because he hates his father. That shows how afraid he is. He sometimes discusses his problems with me after several appeals. Most of the time he prefers not to discuss them with anyone."

From the above findings, it can be seen that children living with partners experiencing failed marriages do not have a cordial relationship with their parents. Some tend to associate themselves with one of the parents and resent the other one; some feel unsafe associating with both parents, and as result withdraw from home life. The findings are in agreement with those of Harold et al. (2004) about marital conflict and child emotional security, who found that marital conflict between couples significantly predicts internalizing and externalizing problems and psychological distress in children who often feel insecure relating to either of the parents. The result also agrees with the findings of another study by Omage (2013) about the issues involved in marriage failure, in which the author found that persistent marital discord between couples affects children's ability to relate to one of the parents (usually the father).

Table 3 Respondents' perception of delinquent behaviors common among children living with spouses experiencing failed marriage

\begin{tabular}{|c|c|c|c|c|c|c|c|}
\hline Items & *Groups & $\begin{array}{l}\text { Strongly } \\
\text { Agree }\end{array}$ & Agree & $\begin{array}{l}\text { Strongly } \\
\text { Disagree }\end{array}$ & Disagree & Frequency & Total \\
\hline \multirow{2}{*}{$\begin{array}{c}\text { Aggression } \\
\text { and } \\
\text { bullying }\end{array}$} & A & $18(28.6 \%)$ & $38(60.3 \%)$ & $0(0 \%)$ & $7(11.1 \%)$ & 63 & \multirow{2}{*}{125} \\
\hline & B & $21(33.9 \%)$ & $30(48.4 \%)$ & $0(0 \%)$ & $11(17.7 \%)$ & 62 & \\
\hline \multirow[b]{2}{*}{$\begin{array}{c}\text { Out of } \\
\text { parental } \\
\text { control }\end{array}$} & A & $14(22.2 \%)$ & $32(50.8 \%)$ & $\begin{array}{c}11 \\
(17.5 \%)\end{array}$ & $\begin{array}{c}6 \\
(9.5 \%)\end{array}$ & 63 & \multirow[b]{2}{*}{125} \\
\hline & B & $16(25.8 \%)$ & $24(38.8 \%)$ & $3(4.8 \%)$ & $19(30.6 \%)$ & 62 & \\
\hline \multirow[b]{2}{*}{$\begin{array}{c}\text { Truancy } \\
\text { and peer } \\
\text { influence }\end{array}$} & A & $21(33.3 \%)$ & $38(60.3 \%)$ & $0(\%)$ & $4(6.4 \%)$ & 63 & \multirow[b]{2}{*}{125} \\
\hline & B & $16(25.8 \%)$ & $42(67.7 \%)$ & $0(0 \%)$ & $4(6.5 \%)$ & 62 & \\
\hline
\end{tabular}

Source: Based on authors' survey (2016). *A-Counselors, B-Social workers 
Respondents' perceptions of common delinquent behaviors among children living with spouses experiencing failed marriage are presented in Table 3. The results show that $28.6 \%$ and $60.3 \%$ of respondents (counselors) strongly agree (agree, respectively) that aggression and bullying are common behaviors among children living with partners experiencing failed marriage, while $11.1 \%$ disagree. In addition, $22.2 \%$ and $50.8 \%$ of the respondents strongly agree (agree) that being out of parental control is common among children living with partners experiencing failed marriage, while $17.5 \%$ and $9.5 \%$ of respondents strongly disagree (disagree), respectively. Also, 33.3\%/60.3\% of respondents strongly agree (agree) that truancy and peer influence are common delinquent behaviors among children living with partners experiencing failed marriage, while $6.4 \%$ of respondents disagree.

Furthermore, $33.9 \%$ and $48.4 \%$ of respondents (social workers) strongly agree (agree) that aggression and bullying are common behaviors among children living with partners experiencing failed marriage, while $17.7 \%$ of respondents disagree. In addition, $25.8 \%$ (38.8\%) of respondents strongly agree (agree) that being out of parental control is common among children living with partners experiencing failed marriage, while $30.6 \%$ of respondents disagree. Also, $25.8 \%$ (67.7\%) of respondents strongly agree (agree) that truancy and peer influence are common delinquent behaviors among children living with partners experiencing failed marriage, while $6.5 \%$ of respondents disagree.

The perception of the experts, as analyzed above, is related to the views of partners who are experiencing failed marriage. Female respondent 1 stressed that "My children have seen us scream at each other and fight several times. The situation really affected my daughter (10 years old). She is moody most of the time, truly it has affected her performance at school. I haven't noticed any sign of delinquency in her. However, my two boys (12 and 7 years old) have started behaving strangely, such as being aggressive and fighting. Their class teachers (most especially of the 12-year-old boy) have called to report on them several times. He (the 12-year-old boy) sometimes refuses to answer me when I call on him to do something, and he beats his siblings mercilessly sometimes, although his younger brother (7-year-old boy) always wrestles with him. The only thing they fear is when you threaten to report them to their father. Then they stop and beg me not to. Perhaps because they have seen his handiwork on me....although children generally (most especially, boys) are often stubborn at a certain age. In terms of my boys, I think they are more aggressive towards each other and other children. I guess my marriage is tearing them apart. We caused it."

Also, Female respondent 2 noted that "I think our fights and disagreement are having a serious influence our children's behavior, most especially our son (11 years old). My son has run away from home three times. The first time he 
ran away I was not around then. I had a serious fight with my husband and was forced out to live with a friend for some days. He was found after three days on the street with other street children. Afterwards, he ran away anytime he saw us fight or when I cry.... when I asked him why he ran away from home, he burst into tears and said to me 'please stop fighting with daddy.' I think he couldn't bear the situation anymore. He feels much more comfortable away from home the way I see it."

Table 4 Respondents' perception of the experiences of couples in failed marriage

\begin{tabular}{|c|c|c|c|c|c|c|c|}
\hline Items & *Groups & $\begin{array}{c}\text { Strongly } \\
\text { Agree }\end{array}$ & Agree & $\begin{array}{l}\text { Strongly } \\
\text { Disagree }\end{array}$ & Disagree & Frequency & Total \\
\hline \multirow{2}{*}{$\begin{array}{c}\text { Lack of } \\
\text { intimacy } \\
\text { (affection, } \\
\text { sexual and } \\
\text { emotional } \\
\text { deprivation) }\end{array}$} & A & $\begin{array}{c}35 \\
(55.6 \%)\end{array}$ & $\begin{array}{c}28 \\
(44.4 \%)\end{array}$ & $0(0 \%)$ & $0(0 \%)$ & 63 & \\
\hline & B & $\begin{array}{c}42 \\
(67.7 \%)\end{array}$ & $\begin{array}{c}20 \\
(32.3 \%)\end{array}$ & $0(0 \%)$ & $0(0 \%)$ & 62 & 125 \\
\hline \multirow[b]{2}{*}{$\begin{array}{c}\text { Absence of } \\
\text { communication }\end{array}$} & A & $\begin{array}{c}23 \\
(36.5 \%) \\
\end{array}$ & $\begin{array}{c}37 \\
(58.7 \%) \\
\end{array}$ & $0(0 \%)$ & $3(4.8 \%)$ & 63 & \\
\hline & B & $\begin{array}{c}28 \\
(45.2 \%)\end{array}$ & $\begin{array}{c}34 \\
(54.8 \%)\end{array}$ & $0(0 \%)$ & $0(\%)$ & 62 & 125 \\
\hline \multirow{2}{*}{$\begin{array}{c}\text { Frequent } \\
\text { disagreement, } \\
\text { nagging, fights } \\
\text { and physical } \\
\text { abuse }\end{array}$} & A & $41(65 \%)$ & $22(35 \%)$ & $0(\%)$ & $0(0 \%)$ & 63 & \multirow[b]{2}{*}{125} \\
\hline & B & $\begin{array}{c}53 \\
(85.5 \%)\end{array}$ & $9(14.5 \%)$ & $0(0 \%)$ & $0(0 \%)$ & 62 & \\
\hline
\end{tabular}

Source: Based on authors' survey (2016). *A-Counselors, B-Social Workers

Table 4 presents respondents' responses to a question about the experiences of couples in failed marriage. The table shows that $55.6 \%$ (44.4\%) of counselors strongly agree (agree) that a lack of intimacy (such as affection, emotional and sexual deprivation) is a common experience among partners in failed marriage. However, $36.5 \%$ (58.7\%) also strongly agree (agree) that an absence of communication is common among partners experiencing failed marriage, while $4.3 \%$ of the respondents disagree. In addition, $65 \%$ (35\%) of respondents strongly agree (agree) respectively that frequent disagreement, nagging, fights and physical abuse is common among partners experiencing failed marriage.

In addition, $67.7 \%$ (32.3\%) of social workers strongly agree (agree) that a lack of intimacy (such as affection, emotional and sexual deprivation) is a common experience among partners in failed marriage. $45.2 \%$ (54.8\%) also strongly 
agree (agree) that an absence of communication is common among partners experiencing failed marriage, and $85.5 \%(14.5 \%)$ strongly agree (agree) that frequent disagreement, nagging, fights and physical abuse are common among partners experiencing failed marriage.

From the interviews, Female respondent 1 noted that "Every marriage is faced with one challenge or another. The stress and challenges are double for partners that are not getting along. There is always emotional and psychological distress. Continuous disagreements and fighting over issues, beating and physical abuse and sexual deprivation are part of the common challenges and experiences faced by women in failed or unhealthy marriage. You sometimes feel like not going home, but for the sake of the children, you have to." Also, Female respondent 2 stressed that "The list of the experiences women encounter in such marriage is endless. Emotional torture, shouting, beating, and all forms of physical abuse and sometimes rape when you are trying to deny them sex just to protest the way you are being treated. It is an unpleasant experience." In addition, the Male respondent pointed out that "We experience frequent disagreements which often leads to nagging and sometimes fighting. There is a complete absence of communication and misunderstanding. I think they (women) feel the effects much more than us (men)."

From the above findings, it can be observed that partners experiencing failed marriage undergo specific challenges or difficulties, although there may be variation in the impacts.

Table 5 Mean and Chi-square analysis of the experiences of spouses in failed marriage and delinquent behaviors

\begin{tabular}{|l|c|c|c|c|}
\hline Items & Mean & DF & X2 & X-Value \\
\cline { 1 - 1 } Experiences of spouses in failed marriage & & & & \\
\cline { 1 - 1 } $\begin{array}{l}\text { Lack of intimacy, absence of communication, } \\
\text { Frequent disagreement, fights, and nagging }\end{array}$ & \multirow{2}{*}{7.24} & 4 & 67.300 & 9.488 \\
\cline { 1 - 2 } Delinquent behaviors & & & & \\
\cline { 1 - 3 } $\begin{array}{l}\text { Aggression, out of parental control, truancy, } \\
\text { bullying, and peer influence }\end{array}$ & & & & \\
\hline
\end{tabular}

Source: Based on authors' survey (2016)

Table 5 shows the cross-tabulation of the mean and calculated chi-square of respondents' perception of the experiences of partners in failed marriage and the implications for delinquent behaviors. The figures indicate that the calculated chi-square $\mathrm{X}^{2}=67.300$ is greater than the critical value 9.488 at the 4 degree of freedom and 0.05 level of significance. Since the chi-square observed value 
is greater than the critical value, one can assume that there is a relationship between partners' experiences in failed marriage and delinquency in children living in homes with such situations.

From the above-described findings it can be deduced that there is a relationship between partners' experiences and the challenges of failed marriage and juvenile delinquent behaviors such as aggression, being out of parental control, truancy, bullying and peer association. This finding corroborates the work of O'Flynn (1994) who found that children living in an unfavorable environment such as an unhealthy home where necessary components such as love, caring, and emotional support are lacking, and where there are frequent fights and physical abuse between partners, may be at high risk of psychological disorder, antisocial attitudes, aggression, and challenges managing anger as adolescents, and be highly influenced by their peers. Furthermore, the results are also in line with the findings of Cummings and Davies (1994) who reported that continuous fighting or conflict amongst parents increases children's exposure to different behavioral, emotional and social problems such as aggression, truancy, and other delinquent acts.

\section{SCOPE AND LIMITATIONS}

The study is not without its limitations. It was conducted only in the Ilorin Metropolis of Kwara State, Nigeria. Obtaining access to information about failed marriage and those experiencing it in Ilorin is difficult because of the religious and cultural values that make marriage a sensitive and private matter, and the stigma partners may face when information about their marriage enters the public domain. The present study investigated the perception of experts and interviewed only a few individuals experiencing failed marriage. Measures were self-reported. For this reason, there is bound to be bias in the responses. Nonetheless, the study was able to grasp the challenges of failed marriages and its effect on children. In this regard, it is expected to stimulate further research of this nature.

\section{CONCLUSION AND RECOMMENDATIONS}

Disagreements in a marriage are inevitable because they are part of every social interaction. How partners manage or control them determines how they 
get along. However, the best environment in which to learn how to handle disagreements is within the family or with loved ones. When children watch their parents continually fight, they are liable to develop the same habits and believe this is the best way to handle things. Poor conflict management in marriage permanently weakens the parent-child relationship and results in destructive ways of handling conflict and the poor self-image of children later in life. Based on the findings and literature that was reviewed, the following strategies are recommended to help create a happy family and a conducive environment for children:

Marriage needs acceptance, admiration, appreciation, and emotional safety. Spouses should try to work things out as much as possible by appreciating, accepting and admiring each other and remember what they saw in each other before marriage. In addition, it is always very difficult and sometimes disrespectful to try to change a spouses' thinking or ideology through threats, mockery, or nagging. These types of approaches attack one's personality, character, and intelligence, and even undermine the mutual respect that forms the basis of love. Couples should try their best to devise a better way of understanding each other's differences instead of nagging, criticizing and attacking each other. Moreover, communication is an important element of a successful marriage and is a process that requires patience. Couples should find all possible means to communicate because it is this factor that holds a marriage together.

Moreover, many marital problems are caused by numerous factors couples may find difficult to identify, discuss and fix. Partners who are experiencing difficulties in their marriage and who are willing to resolve conflicts and live peacefully need to seek out experts who can mediate, such as counselors, social workers, and psychotherapists who can help them to understand the source of the conflict and suggest how to work through the process of resolving their grievances. Marriage experts are often in the best position to analyze the likely challenges partners are experiencing. Marriage experts now practice in collaboration with legal experts, mental health professionals and other specialists to offer various options to partners who experience difficulties in their marriage in terms of learning coping strategies and conflict resolution skills.

Furthermore, one of the most important services that many people ignore in Ilorin metropolis is premarital counselling. People believe marriage is a private issue that does not need the intervention of third parties or strangers. However, premarital counselling is one of the best marriage-related tools for helping partners to understand themselves, the tasks that lie ahead, and the potential challenges of marriage. Young people should be sensitized by the various religious and social organizations about the importance of pre-marital counselling. 
Finally, children who have experienced and been affected by the situation of failed marriages should be encouraged to visit experts for the possible rehabilitation and realignment of their feelings and thoughts about the way their parents handle situations at home. They need love and affection from both parents, even if they do not get along.

\section{REFERENCES}

Beckham, Kathryn (1992), Choice, Not Chance: Enhancing Your Marital Relationship, Columbus, Ohio State University and Ohio Cooperative Extension Service.

Bianchi, Suzanne M. - Melissa, Milkie A. (2010), "Work and Family Research in the First Decade of the 21st Century" Journal of Marriage and Family Vol. 72, No 3, pp. 705-725. https://doi.org/10.1111/j.1741-3737.2010.00726.x

Blood, Robert, O. Jr.; - Donal, Wolfe M. (1960), Husbands and Wives: The Dynamics of Married Living, New York, Free Press.

Booth, Alan - John, Edwards N. (1985), "Age at Marriage and Marital Instability", Journal of Marriage and the Family Vol. 47, No 1, pp. 67-75. https://doi.org/10.2307/352069

Booth, Alan-David, Johnson R.-Ann, Branaman-Alan, Sica. (1995), "Belief and Behavior: Does Religion Matter in Today's Marriage?", Journal of Marriage and the Family Vol. 57, No 3, pp. 661-671. https://doi.org/10.2307/353921

Buijzen, Moniek - Patti, Valkenburg, M. (2003), "The Effects of Television Advertising on Materialism, Parent-child Conflict, and Unhappiness: A Review of Research", Journal of Applied Developmental Psychology Vol. 24, No 4, pp. 437-456. https://doi.org/10.1016/S0193-3973(03)00072-8

Bumpass, Larry L. (1994), The Declining Significance of Marriage: Changing Family life in the United States, Wisconsin: Center for Demography and Ecology, University of Wisconsin.

Burns, Ailsa. (1984), "Perceived Causes of Marriage Breakdown and Conditions of Life", Journal of Marriage and the Family Vol. 46, No 3, pp. 551-562. https://doi.org/10.2307/352597

Burr, Wesley R. (1976), Successful Marriage: A Principles Approach, Homewood, Dorsey Press.

Busari, A. (2011), Psychology of Child Development: A Dynamic Approach, (2nd ed.), Ibadan, Nigeria: Glory-Land Publishing Company.

Carrère, Symbil - Buehlman, Kim T., - Gottman, John M., - Coan, James A., Ruckstuhl, L. (2000), "Predicting Marital Stability and Divorce in Newlywed 
Couples", Journal of Family Psychology Vol. 14, No 1, pp. 42-58. https://doi. org/10.1037/0893-3200.14.1.42

Choi, Heejeong - Nadine, Marks F. (2008), "Marital Conflict, Depressive Symptoms, and Functional Impairment", Journal of Marriage and Family Vol. 70, No 2, pp. 377-390.

Cleary, Paul D., - David, Mechanic (1983), "Sex Differences in Psychological Distress among Married People", Journal of Health and Social Behavior Vol. 24, No 2, pp. 111-121.

Cummings, Mark E., - Davies, Patrick T. (1994), Children and Marital Conflict: The Impact of Family Dispute and Resolution, New York, Guilford Press.

Davies, Patrick T., - Sturge-Apple, Melissa L., - Dante, Cicchetti - Cummings Mark E. (2008), "Adrenocortical Underpinnings of Children's Psychological Reactivity to Inter-parental Conflict", HHS Public Access Journal Vol. 79, No 6, pp. 1693-1706. https://doi.org/10.1111/j.1467-8624.2008.01219.x

Davies, Patrick T., - Cummings, Mark E. (1994), "Marital Conflict and Child Adjustment: An emotional Security Hypothesis", Psychological Bulletin Vol. 116, No 3, pp. 387-411. https://doi.org/10.1037/0033-2909.116.3.387

Edin, Kathryn - Joanna, Reed M. (2005), "Why Don't they Just Get Married? Barriers to Marriage among the Disadvantaged", The Future of Children Vol. 15, No 2, pp. 117-137.

Ekiran, MA (2003), Marriage and the Family: A Sociological Perspective, Lagos, Nigeria: Rebonik.

Fincham, Frank D., - Steven, Beach RH. (1999), "Conflict in Marriage: Implications for Working with Couples", Annual Review of Psychology Vol. 50, No 1, pp. 47-77. https://doi.org/10.1146/annurev.psych.50.1.47

Glaser, Danya. (2002), "Emotional Abuse and Neglect (Psychological Maltreatment): A Cnceptual Framework", Child Abuse \& Neglect Vol. 26, No 6, pp. 697-714. https://doi.org/10.1016/S0145-2134(02)00342-3

Glenn, Norval D.,- Michael, Supancic. (1984), "The Social and Demographic Correlates of Divorce and Separation in the United States: An Update and Reconsideration", Journal of Marriage and the Family Vol. 46, No 3, pp. 563575. https://doi.org/10.2307/352598

Gottman, John M. (1993), "The Roles of Conflict Engagement, Escalation, and Avoidance in Marital Interaction: A Longitudinal view of Five Types of Couples", Journal of Consulting and Clinical Psychology Vol. 61, No 1, pp. 6-15. https://doi.org/10.1037/0022-006X.61.1.6

Grych, John H., - Michael, Seid - Frank, Fincham D. (1992), "Assessing Marital Conflict from the Child's Perspective: The Children's Perception of Interparental Conflict Scale", Child Development Vol. 63, No 3, pp. 558-572. https://doi.org/10.1111/j.1467-8624.1992.tb01646.x 
Harold, Gordon T., - Shelton, Kathrine H., - Goeke-Morey, Marcie C., Cummings, Mark E. (2004), "Marital Conflict, Child Emotional Security about Family Relationships and Child Adjustment", Social Development Vol. 13, No 3, pp. 350-376. https://doi.org/10.1111/j.1467-9507.2004.00272.x

Hassouneh-Phillips, Dena S. (2001), "Marriage is Half of Faith and the Rest is Fear Allah" Marriage and Spousal Abuse Among American Muslims", Violence Against Women Vol. 7, No 8, pp. 927-946.

Hetherington, Mavis E., - Bridges, Margaret - Glendessa, Insabella M. (1998), "What Matters? What Does not? Five Perspectives on the Association Between Marital Transitions and Children's Adjustment", American Psychologist Vol. 53, No 2, pp. 167-184. https://doi.org/10.1037/0003-066X.53.2.167

Hoeve, Machteld - Stams, Geert Jan. J.,- Van der-Put, Claudia E., - Dubas, Semon Judith - Van der-Laan, Peter H., - Gerris, Jan R., (2012), "A MetaAnalysis of Attachment to Parents and Delinquency", Journal of Abnormal Child Psychology Vol. 40, No 5, pp. 771-785.

Kaplan, Andreas M., - Michael Haenlein. (2010), "Users of the World, Unite! The Challenges and Opportunities of Social Media", Business Horizons Vol. 53, No 1, pp. 59-68. https://doi.org/10.1016/j.bushor.2009.09.003

Kiecolt-Glaser, Janice K., - Tamara, Newton L. (2001), "Marriage and Health: His and Hers", Psychological Bulletin Vol. 127, No 4, pp. 472.

Kirman, Brian H. (1973), "Emotional Deprivation in Children", British Medical Journal Vol. 3, No 5873, pp. 240.

Kozu, Junko. (1999), "Domestic Violence in Japan", American Psychologist Vol. 54, No 1, pp. 50-54. https://doi.org/10.1037/0003-066X.54.1.50

Lerner, Richard M., - Domini, Castellino R. (2013), Adolescents and Their Families: Structure, Function, and Parent-Youth Relations, New York, Routledge.

Manning, Wendy D. - Monica A. Longmore, - Peggy C. Giordano. (2007), "The Changing Institution of Marriage: Adolescents' Expectations to Cohabit and to Marry", Journal of Marriage and Family Vol. 69, No 3, pp. 559-575. https:// doi.org/10.1111/j.1741-3737.2007.00392.x

Matthews, Lisa S., - Wickrama, K. A. S.,- Rand, Conger D. (1995), "Predicting Marital Instability from Spouse and Observer Reports of Marital Interaction", Journal of Marriage and the Family Vol. 58, No 3, pp. 641-655. https://doi. org/10.2307/353725

McCarthy, Barry, - McCarthy, Emily J. (2005), Getting it Right the First Time: Creating a Healthy Harriage, London, Routledge.

O’Flynn, Al. (1994), "Using Object Relations Theory to Understand Childhood Deprivation", The Journal of the New York State Nurses' Association Vol. 25, No 4, pp. 9-12. 
O'Hagan, Kieran. (1993), Emotional and Psychological Abuse of Children, Buckingham, Open University Press.

Omage, Mannie I., (2013), "Critical Issues in Marriage Failure in Benin City, Nigeria: Signaling the Way Forward", European Scientific Journal Vol. 9, No 5, pp. 324-337.

Ooms, Theodora. (2007), Adapting Healthy Marriage Programs for Disadvantaged and Culturally Diverse Populations: What are the Issues?, Washington, DC, Center for Law and Social Policy.

Perry, Cheryl L., - Steven, Kelder H. (1992), "Models for Effective Prevention", Journal of Adolescent Health Vol. 13, No 5, pp. 355-363. https://doi. org/10.1016/1054-139X(92)90028-A

Raush, Harold L., - Barry, William. A., - Hertel, Richard K., - Swain, Mary A. (1974), Communication Conflict and Marriage, Oxford, Englan: Jossey-Bass. Ray, Munni - Kana, J. R. (2010), "Effect of Electronic Media on Children", Indian Pediatrics Vol. 47, No 7, pp. 561-568. https://doi.org/10.1007/s13312010-0128-9

Richard, Heyman E., - Amy, S.-S. M. (2001), "The Hazards of Predicting Divorce without Cross-validation", Journal of Marriage and Family Vol. 53, No 2, pp. 473-479. https://doi.org/10.1111/j.1741-3737.2001.00473.x

Robles, Theodore F., - Richard, Slatcher B., - Joseph, Trombello M., - Meghan, McGinn M. (2014), "Marital Quality and Health: A Meta-Analytic Review", Psychological Bulletin Vol. 140, No 1, pp. 140.

Seltzer, Judith A., (2000), "Families formed outside of Marriage", Journal of Marriage and Family Vol. 62, No 4, pp. 1247-1268. https://doi.org/10.1111/ j.1741-3737.2000.01247.x

Tikumah, Issah H. (2009), An introduction to the Study of Problems in Society for Tertiary Students in Nigeria, Zaria, Ahmadu Bello University Press Limited.

Waite, Linda J., - Lee, Lillard A. (1991), "Children and Marital Disruption", American Journal of Sociology Vol. 96, No 4, pp. 930-953. https://doi. org/10.1086/229613

Wood, Robert G., - Quinn, Moore - Andrew, Clarkwest - Alexandra, K. (2014) "The Long-term Effects of Building Strong Families: A Program for Unmarried Parents", Journal of Marriage and Family Vol. 76, No 2, pp. 446463. https://doi.org/10.1111/jomf.12094

Wood, Robert G., - Sheena, McConnell - Quinn, Moore - Andrew, Clarkwest - JoAnn, H. (2012), "The Effects of Building Strong Families: A Healthy Marriage and Relationship Skills Education Program for Unmarried Parents", Journal of Policy Analysis and Management Vol. 31, No 3, pp. 228-252. https://doi.org/10.1002/pam.21608 


\section{APPENDIX}

Demographic information of participants $(n=125)$

\begin{tabular}{|c|c|c|}
\hline Gender & Frequency & Percentage (\%) \\
\hline Male & 71 & 57 \\
\hline Female & 54 & 43 \\
\hline Total & 125 & 100 \\
\hline Age & Frequency & Percentage (\%) \\
\hline $30-35$ & 38 & 30.4 \\
\hline $36-40$ & 61 & 48.8 \\
\hline 41-above & 26 & 20.8 \\
\hline Total & 125 & 100.0 \\
\hline Marital status & Frequency & Percentage (\%) \\
\hline Single & 05 & 4 \\
\hline Married & 75 & 60 \\
\hline Divorced & 19 & 15.2 \\
\hline Widow/widower & 26 & 20.8 \\
\hline Total & 125 & 100 \\
\hline Profession & Frequency & Percentage (\%) \\
\hline Counsellor & 63 & 40.4 \\
\hline Social worker & 62 & 49.6 \\
\hline Total & 125 & 100.0 \\
\hline Years of experience & Frequency & Percentage (\%) \\
\hline $1-10$ years & 34 & 27.2 \\
\hline $11-20$ years & 48 & 38.4 \\
\hline 21- above & 43 & 34.4 \\
\hline Total & 125 & 100 \\
\hline
\end{tabular}

Source: Based on authors'survey (2016). 